LA- -92.75-HDR

DE82 014128

\title{
Seasat-Satellite Investigation of the Structure of Western Nebraska and Its Application to the Evaluation of Geothermal Resources
}

John Stix

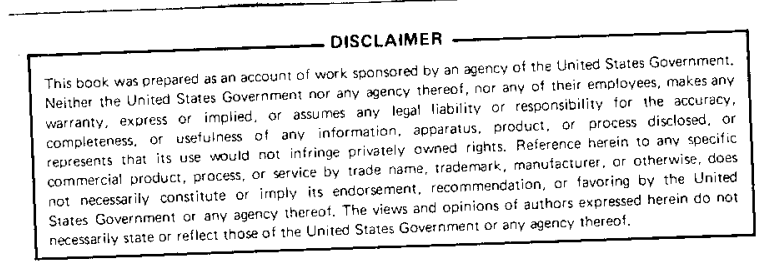




\section{DISCLAIMER}

This report was prepared as an account of work sponsored by an agency of the United States Government. Neither the United States Government nor any agency Thereof, nor any of their employees, makes any warranty, express or implied, or assumes any legal liability or responsibility for the accuracy, completeness, or usefulness of any information, apparatus, product, or process disclosed, or represents that its use would not infringe privately owned rights. Reference herein to any specific commercial product, process, or service by trade name, trademark, manufacturer, or otherwise does not necessarily constitute or imply its endorsement, recommendation, or favoring by the United States Government or any agency thereof. The views and opinions of authors expressed herein do not necessarily state or reflect those of the United States Government or any agency thereof. 


\section{DISCLAIMER}

Portions of this document may be illegible in electronic image products. Images are produced from the best available original document. 
SEASAT SATELLITE INVESTIGATION OF THE STRUCTURE OF WESTERN NEBRASKA AND ITS APPLICATION TO THE EVALUATION _OF GEOTHERMAL RESOURCES

by

John Stix

\title{
ABSTRACT
}

\begin{abstract}
Seasat synthetic aperture radar (SAR) satellite imagery was used to interpret the structural framework and, indirectly, the geothermal potential of an area in western Nebraska. Lineaments were mapped from the imagery and then compared to known structure. It was found that Seasat does record surface manifestations of subtle basement structures, particularly faults and joints. Furthermore, two areas with hot dry rock geothermal potential were delineated using Seasat and other data. It is stressed that more subsurface geology and geophysical data are needed before a final evaluation of the geothermal potential can be made. Seasat imagery is a useful reconnaissance exploration tool in the interpretation of regional structure within areas of little topographic relief.
\end{abstract}

\section{INTRODUCTION}

The purpose of using Seasat synthetic aperture radar (SAR) satellite imagery in western Nebraska was to see if surface expression of subtle structural features in an area of little relief could be detected using this remote sensing technique. Primary objectives of this study were to examine folds, faults, fractures, and joints using this method; if these structures could be detected, a further examination tried to separate structural forms. Such a reconnaissance is especially promising in the context of a larger exploration program; it is a way to save time and money in pinpointing specific areas for more detailed subsurface geological and geophysical exploration.

The area in question is interesting from a geothermal standpoint, as there is a geothermal anomaly, based on silica and sodium-potassium-calcium (Na-K-Ca) geothermometry, covering much of western Nebraska (Swanberg and Morgan 1978; Midcontinent Hot Dry Rock Study Group 1980). Since geothermal anomalies appear to be related to the structural features in western Nebraska, Seasat imagery was used to pinpoint other areas of geothermal potential. 


\section{REGIONAL STRATIGRAPHY AND STRUCTURE OF WESTERN NEBRASKA}

Precambrian basement rock types along the Cambridge arch (Fig. 1) are better known than in adjacent areas due to the relative thinning of sedimentary section over the arch and the greater number of oil and gas drill holes that have reached the Precambrian surface. Much information is still needed to accurately portray basement lithology, but it is known that there is quite a complex assemblage of rocks. Within the area the distribution of granites, schists, granofels, and gneisses has been generally delineated (Plate 1, inside back cover) (Lidiak 1972). Rubidium-Strontium and Potassium-Argon ages of the schists, granofels, and gneisses suggest that Precambrian metamorphic rocks of the Cambridge arch and adjoining area are not younger than 1800 Myr b.p., probably of Precambrian X age (Lidiak 1972).

Merriam and Atkinson (1955) stated that biotite granites have intruded the older metamorphic rocks and are younger than $1800 \mathrm{Myr}$ b.p. Lidiak (1972) and Zietz and others (1966) have agreed with this theory by noting the circular shapes, absence of foliation, magnetic highs, and northeast-trending lithologic anomalies of these granitic bodies. Lidiak (1969, 1972) has suggested three periods of granite emplacement in Nebraska; the earliest occurred 1700 Myr b.p. in northwestern Nebraska, from 1570 to 1580 Myr b.p. in southern Nebraska, and between 1510 and 1540 Myr b.p. in northern Nebraska and southern South Dakota. However, the ages of the latter two periods of plutonism may be older due to later widespread thermal activity that may have reset radiogenic clocks.

Along the crest of the Chadron-Cambridge arch, sediment thicknesses range from $900 \mathrm{~m}$ in northwestern Nebraska to $1300 \mathrm{~m}$ in the west-central region to $1250 \mathrm{~m}$ in southwestern Nebraska. The arch system is asymmetric; sediments thicken rapidly west of the Chadron arch, while the section thickens more gradually to the east of the arch (Wulf 1964). In contrast, the opposite occurs in the Cambridge arch area, with the section thickening more rapidly to the east of the arch than to the west (Carlson 1966).

The sedimentary section on the flanks of the arch system is characterized by unconformities and thickening of Pennsylvanian, Permian, Triassic, and Cretaceous rocks away from the arch axes (King 1951; Wulf 1964). Pre-Cenozoic rock units that overlie the crest of the Chadron-Cambridge system are thinner than those on the flanks of the arch due to depositional control by the arch and to unconformities caused by the erosion of beds as the arch system was uplifted periodically. Figure 2 shows a generalized regional stratigraphy for western Nebraska.

In Cambrian through Mississippian time, deposition was minimal. A highland area was coincidental with the arch (Table I) (Wulf 1964). Much of what was deposited up through Mississippian time was removed at the end of that period during broad uplift of the arch and erosion, resulting in a widespread unconformity (Larson 1962). Transgression in the Pennsylvanian thoroughly buried the arch under marine sediments (Wulf 1964); thickness and distribution of facies was controlled here by the movement of the arch.

The Cambridge arch was less active than the Chadron arch during the Permian, whereas during Early Cretaceous time the opposite was the case (Moore and Nelson 1974). Very little Triassic and Jurassic sedimentation occurred on the arch system due to continued uplift and erosion there (Larson 1962).

Post-Laramide Tertiary sediments were unconformably deposited over folded Paleozoic and Mesozoic sedimentary rocks (Larson 1962; Wulf 1964). 


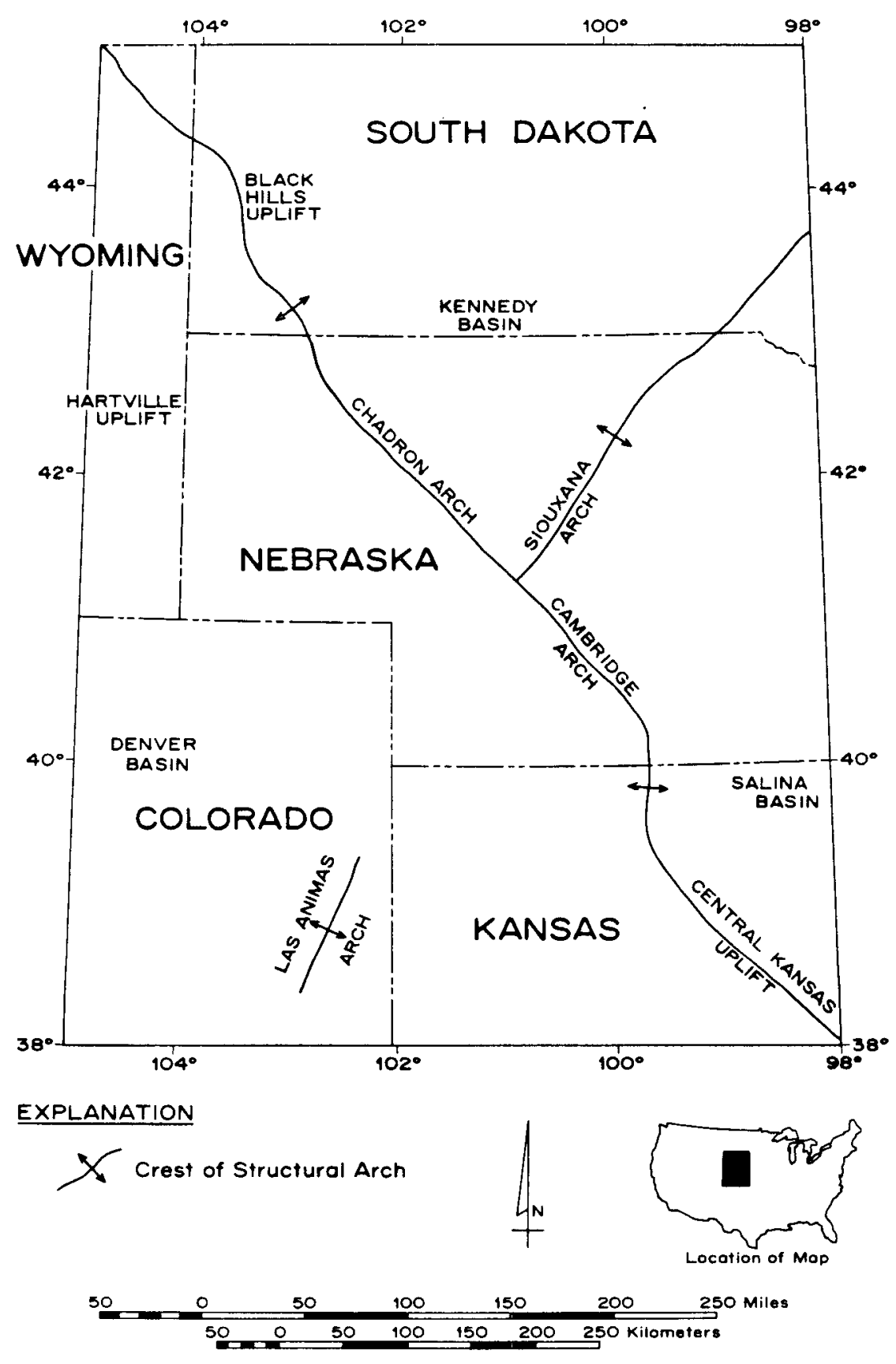

Fig. 1.

Major tectonic elements of the central Cordilleran foreland (modified from Bayley and Muehiberger 1968). 


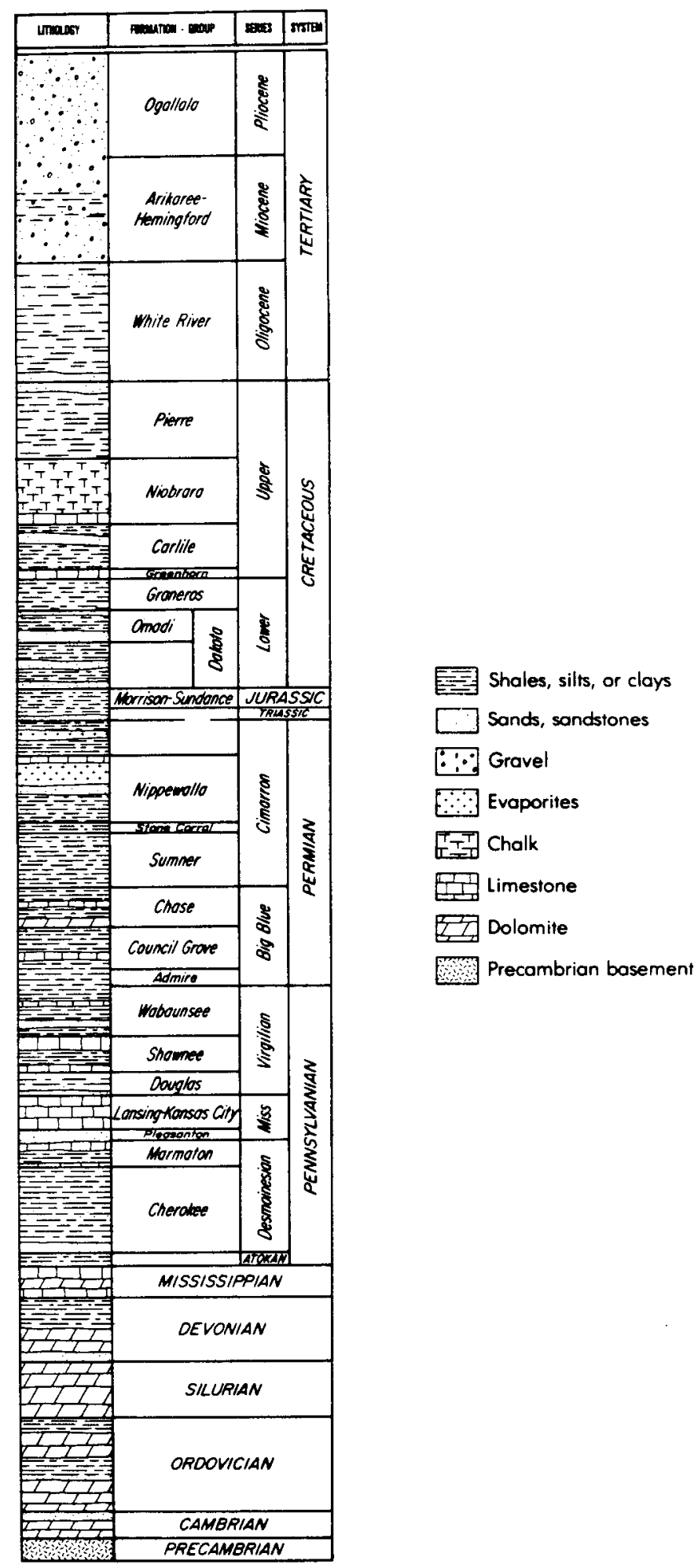

Fig. 2 .

Generalized Phanerozoic stratigraphy of western Nebraska (modified from Burchett 1969, and Moore and Nelson 1974, Figure 1). 
TABLE I

PHANEROZOIC UPLIFT OF THE CAMBRIDGE ARCH

Data from Larson 1962

Schisler, A., independent geologist, Golden, Colorado, personal communication (1980)

Stanley 1971

Stanley and Wayne 1972

Wulf 1964

Period of Uplift

Early Ordovician

Latest Devonian

Latest Mississippian

Pennsylvanian

Latest Permian to Triassic

Early Cretaceous

Late Cretaceous to Early

Tertiary (Laramide)

01 igocene

Pleistocene
Evidence

Erosional unconformities

Erosional unconformities

Erosional unconformities

Thinning of sedimentary beds over uplift

Non-deposition

Facies changes (transgression)

Erosional unconformities

Warping of beds

Drainage patterns, facies changes

A. Tectonic Framework and History

Plate 2 (inside back cover) shows the known structural features of the area. Note that the structural framework is only generally known as almost all of the information is based on unpublished oil and gas well data.

The most prominent Precambrian basement feature in western Nebraska is the northwest-trending Chadron-Cambridge arch system (Fig. 1), which extends northwest from the Central Kansas Uplift to the Black Hills Uplift. The different elements of the arch system cannot, however, be considered together in terms of tectonic activity, as each part of the system has been active at different times during. the Phanerozoic. Regionally, there has been a northwest progression of tectonic activity. with time (Merriam and Atkinson 1955). It has been suggested that the Cambridge arch is related more closely in time to the northeast-trending Siouxana arch than to the Chadron arch or Central Kansas Uplift (Barr and Bieber 1961). Uplift of the Black Hills may have occurred later than that of the Chadron arch; likewise, Cambridge arch tectonic activity came before that of the Chadron, and movement on the Central Kansas Uplift preceded Cambridge movement. Initial uplift of the Cambridge arch is believed to have occurred during Paleozoic time, although similar tectonic activity on the Chadron arch and Black Hills Uplift is thought to have occurred during the Mesozoic (Barr and Bieber 1961).

The Cambridge arch has been active intermittently throughout the Phanerozoic; movements are summarized in Table I. Additionally, Stanley and Wayne (1972) have noted recent movement on the arch, as evidenced by abrupt changes in river courses over the arch, drainage patterns, and antecedent streams in 
the region. Further, woollard (1958) has recorded earthquakes along the arch, and Farquhar (1957) has noted activity on the system in Kansas. He noted that this is primarily a vertical movement rather than horizontal shortening. This relation is true for the system as a whole, as these movements through time have been epeirogenic rather than orogenic. These observations of activity along the arch are supported by Adams' (1980) data demonstrating present-day tilting of the midcontinent region.

In summary, the recurrent uplift along the Cambridge-Chadron system suggests a fundamental zone of weakness that has existed since late Middle Precambrian time (Osterwald and Dean 1961).

Steep dips encountered during drilling show possible faults (Curtis 1959; Wulf 1964; Schisler*). Sediments draped over an anomalously steep Precambrian surface suggest basement faulting, as the configuration of different sedimentary surfaces reflects basement topography on structure contour maps of this area. Thus, there is a corresponding steep dip of the sediments and a thickening of sedimentary section. It is possible that the sediments were deposited over Precambrian basement ridges, causing the anomalously steep dips on either side; faulting would not be necessary in this case. To a lesser extent, steep dips also may be due to differential compaction of sediments and recurrent uplift (King 1951). But such theories can be el iminated with regard to the mapped steep dips. Sedimentary isopachous maps do not show thickening on the flanks and thinning in the middle as would be expected with such a draping over basement knobs (Larson 1962). Larson (1962) al so has found greater fracturing in limestones where steep dip occurs on structure contour maps. Furthermore, it is suggested that the development of faulting occurred simultaneously with epeirogenic movement on the arch (Larson 1962; Moore and Nelson 1974). Thus, uplift of the arch, erosion and resulting deposition of sediments off the arch, and basement faulting are essentially contemporaneous. Further sedimentary deposition can occur a short time after the onset of faulting. Also, it is important to realize that the epeirogenic movement on the Cambridge-Chadron system is essentially vertical. Lidiak (1972) has noted little, if any, Phanerozoic lateral strike-slip movement in the region, although west-northwest and west-trending Precambrian cataclastic shear zones are prominent in several areas (Plate 1). This fact is corroborated by the style of faulting, an extremely high angle displacement (Schisler*). Such high angle faulting makes the verification of steep dip as a manifestation of subsurface faulting an extremely difficult task, as there is no addition or removal of section recognizable from electric log data on either side of a fault.

Further evidence of faulting is provided by steep gradients in aeromagnetic data in places where Precambrian basement lithologic contacts are not observed from drilling records (Zietz and others 1966); contacts between Precambrian lithologic units are from Lidiak (1972) and shown in Plate 1.

Faults, steep dips, and steep aeromagnetic gradients, shown on Plate 2 , trend generally northwest and parallel the strike of the Cambridge arch (Zietz et al., 1966), indicating that these structures are related to the arch and were created during epeirogenic uplift. In contrast, few known structures trend parallel to the Siouxana arch, suggesting that the Siouxana is and was less active tectonically than the Cambridge arch. Alternatively, there may be a lack of data for this area.

*Schisler, A., independent geologist, Golden, Colorado, personal communication (1980). 
Folding in the area, shown on Plate 2, exhibits two distinct trends. The first roughly parallels the Cambridge system. As an example, the folds centered south of $\mathrm{N}^{\circ} 0^{\circ}$ latitude and W101 $30^{\prime}$ longitude show a change in trend direction from southerly to southwesterly, suggesting that folds are affected by and follow the strike of the arch. The folding may have formed as buckling and/or gravity sliding occurred with periodic uplift of the arch. A second distinct trend of folds is recognized centered about $N 40^{\circ} 45^{\prime}$ latitude, $W 101^{\circ} 30^{\prime}$ longitude. These anticlines and synclines trend east-west but invariably plunge to the west. They are oblique to the arch system, indicating that the folding formed by a different process. The number of folds in this trend increases to the west-northwest off the study area (0sterwald and Dean 1961). The trend may be explained in light of Permian evaporite beds. This cluster of folds corresponds with thick evaporite deposits of Upper Leonardian age in western Nebraska and a 75-m-thick section of Wolfcampian age evaporites in southwestern Nebraska (Rascoe and Baars 1972). Thus, salt tectonics may be partly responsible for deformation of beds into broad, gentle folds along the flanks of the arch. The evaporite deposits are irregular in extent, with abrupt facies changes to clastic rocks in the east in the area of the Cambridge arch. However, it is possible that activity on the Cambridge system could have initiated salt flowage. Perhaps this theory explains the fact that the folds plunge west, away from the arch system, and were caused by slip downdip into the Denver Basin.

\section{SEASAT DATA INTERPRETATION}

\section{A. Characteristics and Techniques}

The Seasat satellite operated through the summer of 1978 at an altitude of $800 \mathrm{~km}$. It carried a synthetic aperture radar (SAR) that was able to image $100-\mathrm{km}$-wide swaths across both land and sea. The $108^{\circ}$ orbital inclination resulted in two 'look' directions for the imagery, one trending northeast and the other northwest. In this manner, certain areas were imaged with two different illumination directions. The incidence angle of the radar beam at $20^{\circ}$ from the vertical was not optimum for geologic purposes as it leads to considerable distortion in topographically rugged areas. This was, however, not a problem in the gentle topography of the area. A description of the Seasat imaging radar and discussions of applications to geology and oceanography can be found in Elachi (1980).

The Seasat SAR system was active, meaning that it transmitted and received its own energy to obtain the image. Thus, Seasat was independent of such variables as sun angle, time of day, and weather conditions. In contrast, the Landsat satellite is a passive system, dependent upon these environmental and physical variables (Lillesand and Kiefer 1979).

Factors that modulate image tone or brightness in a radar image are surface slope and roughness, the scale of the radar operating wavelength, and surface dielectric constant. The Seasat system, with an incidence angle of $20^{\circ}$, is sensitive to slopes near this angle which face the radar. At this wavelength, low fault scarps are bright specular reflectors; and surface roughness causes considerable energy to be backscattered, resulting in a bright image tone.

Plate 3 (inside back cover) is a Seasat image of the study area in western Nebraska. Plate 4 (inside back cover) shows lineaments mapped from the image. These lineaments were chosen according to several criteria. Linear, bright lines which may represent stream channels, scarps, and 
lithologic boundaries were mapped. Tonal variations that suggested either a change in surface lithology or perhaps a fault were recorded. The chances of a surficial lithologic boundary diminish as the linearity of the feature increases, suggesting faulting and/or fracturing. Finally, a line that shows discontinuities to either side strongly suggests that there has been some offset. The last two criteria are especially indicative of faulting, whereas the first may represent joint sets that often appear clearly on satellite imagery.

Possible folding shown on Plate 4 was inferred on the basis of tonal variations on the imagery. Interpretation of folding is difficult in this area, because nearly flat-lying Tertiary sediments lying unconformably above the folded section frequently mask the older geologic structure.

B. Trends on Seasat Imagery

Plate 4 shows the results of interpretation based on seasat imagery. South of $\mathrm{N} 0^{\circ}$ latitude possible broad, gentle folds are shown, trending eastwest (Plate 4). Lineaments do not show up well in this area due to the poor contrast of the image and due to modification of the surface by farming activity. A strong northwest trend is detected to the north of $N 40^{\circ}$ latitude; in fact, this is the dominant trend throughout the northern section of the map as indicated by lineaments visible on Seasat imagery. Furthermore, this trend suggests a relation of the surface landforms to the Cambridge arch. In this area topographic relief is greater than to the south; as a result, a greater number of structural features are expressed on the imagery.

The Siouxana arch cannot be delineated with Seasat imagery (Plate 4). A poorly defined group of lineaments, visible in the area of $N 41^{\circ}$ latitude, W $100^{\circ}$ longitude, may be related to the Siouxana. The Siouxana arch has not been as active as the Cambridge system; this inactivity may account for the lack of well-defined lineaments. Stanley and Wayne (1972), on the basis of minimal Pleistocene movement of the Siouxana, also believe that there has been little recent activity there.

Another subordinate set of east-west linear trends is visible among the dune fields of the Middle Loup River. It is possible that aeolian action has created these lineaments, but structural relief may be visible through the dune deposits and may relate to the movement over salt deposits present to the west of $W 102^{\circ}$ longitude.

Frequency-azimuth histograms were drawn from lineaments on Plate 4 (Fig. 3). Overall, a strong north-northwest trend is observed with a mean azimuth of $335^{\circ}$ for all lineaments (Fig. 3a). This trend is subparallel to the regional northwest strike of the Cambridge arch. However, in this area the arch trends irregularly north-northwest when mapped from exploration drill holes that penetrate the Precambrian surface (Plate 2) (Carlson 1966).

The effect of periodic uplift of the Cambridge arch on lineament orientations can be seen when comparing different areas. Between $N 41^{\circ}-\mathrm{N} 42^{\circ}$ latitude, $W 100^{\circ}-W 101^{\circ}$ longitude, lineaments trend at a mean azimuth of $321^{\circ}$ (Fig. $3 \mathrm{~b}$ ). This number correlates well with an average trend of $322^{\circ}$ of the arch in this area. Additionally, Fig. $3 b$ suggests a bimodal grouping of azimuths. A strong secondary trend striking $270^{\circ}-280^{\circ}$ may reflect the bending of the arch to the west near the Middle Loup River on the northern part of Plate 2 .

Between $N 40^{\circ}$ - $N 41^{\circ}$ latitude, $W 101^{\circ}$ - W102 longitude, lineaments trend again to the northeast (Fig. $3 \mathrm{C}$ ). Removed from the locally fluctuating strike of the arch, the lineaments assume the regional northwest trend of the arch. 

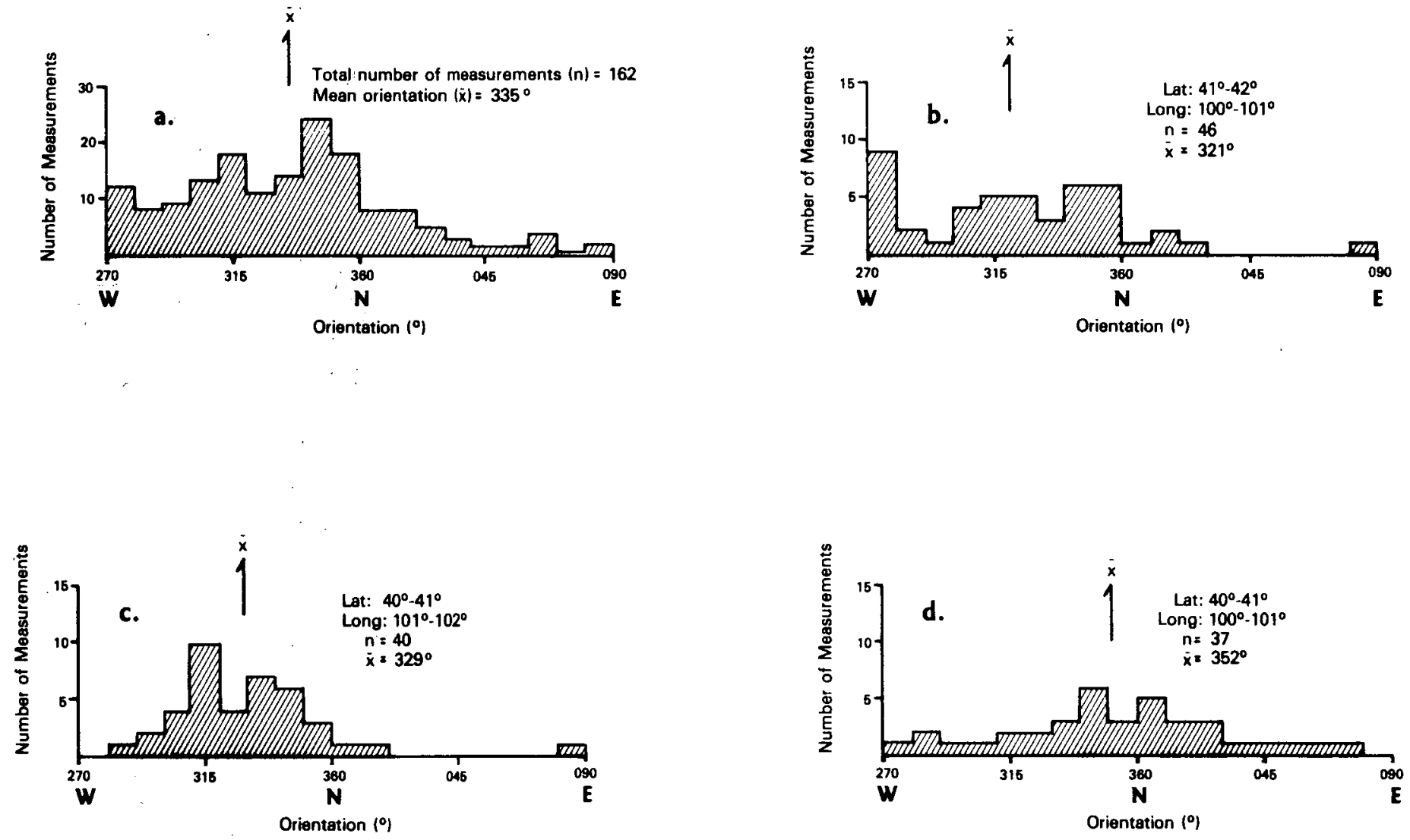

Fig. 3.

Histograms of orientations of lineaments mapped on Plate 4. Fig. 3a represents orientations of all lineaments. Fig. $3 b, 3 c$, and $3 d$ represent orientations of lineaments mapped in individual latitudinal and longitudinal quadrants. 
Between $\mathrm{N} 40^{\circ}$ - $\mathrm{N} 41^{\circ}$ latitude, $\mathrm{W} 100^{\circ}$ - W101 longitude, lineaments trend at a mean azimuth of $352^{\circ}$ (Fig. $3 \mathrm{~d}$ ). This more northerly orientation is reflected to a limited degree by the north-northeast trend of the Cambridge arch in this area. These lineaments strike obliquely to the arch but may parallel the arch as one moves east of the study area.

Thus, if these lineaments are indications of subsurface structure (faulting and fracturing), the strike of the Cambridge arch controls the trend of the lineaments on the crest and flanks of the arch.

A detailed comparison of mapped lineaments to known structure is discussed in the Appendix.

\section{GEOTHERMAL CORRELATIONS}

A. Hot Dry Rock Geothermal Resource

Granitic rocks shown on P1ate 1 were intruded later than the majority of basement rocks in the area (Merriam and Atkinson 1955; Lidiak 1969, 1972). Thus, these are plutonic rocks younger than 1800 Myr b.p. and may have hot dry rock (HDR) geothermal potential because of their composition, age, and radiogenic heat production.

The only indication of hot granites in Nebraska is in the extreme northwest where high heat flow and geothermal gradient values $\left(112 \mathrm{mWm}^{-2}, 66^{\circ} \mathrm{C} / \mathrm{km}\right.$ ) (Gosnold 1981b) suggest that the granitic basement produces radiogenic heat (Plate 1). The granites in the northwest are dated at $1710 \pm 320$ to $1720 \pm 130$ Myr b.p. (Goldich et al. 1966; Lidiak 1969; 1972). There are no heat flow data associated with the granites in the region covered by Seasat (Plate 1). However, these rocks are dated at $1510 \pm 70$ to $1580 \pm 230$ Myr b.p. and are thus younger than the granites in the northwest (Goldich et al. 1966; Lidiak 1969; 1972). The younger age may be an indication of higher radiogenic heat production than the northwestern granites.

It is important for HDR exploration to delineate areas that have little faulting and fracturing in order to minimize fluid loss in the reservoir rock. Thus, granites A and E (Plate 1) may be a good target for HDR investigation because of a lack of cataclasis and mapped Seasat lineaments in this region, although lineament 1 may represent a contact between granite $E$ and the undivided Precambriañ rock. The lack of lineaments suggests minimal faulting and/or fracturing in this area. In contrast, granites B, C, and $D$ appear to have been extensively fractured and faulted according to the lineament analysis shown on Plate 1 and Plate 4. This fact may preclude these areas for HDR exploration because of potentially extensive fluid loss in the granitic reservoir rocks.

Another important consideration for HDR development is that a rock temperature of $200^{\circ} \mathrm{C}$ can be reached within reasonable drilling depths. Unfortunately, there is no heat flow information for granites $A$ and $E$. However, if one postulates a geothermal gradient of $50^{\circ} \mathrm{C} / \mathrm{km}$, a temperature of $200^{\circ} \mathrm{C}$ can be reached by drilling $4 \mathrm{~km}$. For the west 1 imb of granite $A$, one would have to drill through $1.4 \mathrm{~km}$ of mainly low-thermal conductivity Phanerozoic shales (high geothermal gradient) and $2.6 \mathrm{~km}$ of Precambrian granitic rock to reach the 4-km depth and $200^{\circ} \mathrm{C}$ temperature (Carlson 1966). For the east limb of granite $A$, the drilling would penetrate $1.2 \mathrm{~km}$ of sediments and $2.8 \mathrm{~km}$ of granite. Similarly, granite $E$ would require drilling $1.2 \mathrm{~km}$ of sediments and $2.8 \mathrm{~km}$ of granite. These figures fall within economic drilling depths and capabilities. 
For HDR production to be feasible, the granitic basement reservoir rock must have low permeabilities. However, these requirements have been met in granitic rocks at Fenton Hill, New Mexico, the initial HDR test site. Presumably, granites $A$ and $E$ in Nebraska could al so meet these requirements.

Finally, the potential HDR site should be located near a population center. Granites $A$ and $E$ are adjacent to North Platte, a city of 24500 people. In fact, granite A lies just $10 \mathrm{~km}$ to the west of North Platte (Plate 1).

B. Hydrothermal Resource

Published heat flow and geothermal gradient data do not indicate highly anomalous zones of heat flow in southwest Nebraska where there is Seasat coverage (Plate 1) (Gosnold 1981a, 1981b). Thus, the fractures and faults delineated by Seasat in this area probably do not transport hot fluids; the hydrothermal potential in this area appears to be low. However, further heat flow studies are needed to confirm this hypothesis.

Yet, such a Seasat structural study in the northwest and in the panhandle of Nebraska may prove extremely useful. The high regional heat flow and gradients in this area are due primarily to updip of the sedimentary section from the Denver-Julesberg basin eastward to the Chadron-Cambridge arch. Hot water is carried upward by the Cretaceous Dakota aquifer at a rate of $1 \mathrm{~m} / \mathrm{yr}$, and geothermal gradients are enhanced by low thermal conductivity shales in the Phanerozoic section (Gosnold 1981a, 1981b). A Seasat lineament study along the chadron arch would delineate zones of tensional fracturing and faulting caused by periodic uplift of the arch. Such structures have been suggested at the crest of the Cincinnati-Findley arch in western Ohio (Cannon et al. 1980). These faults and fractures represent lines of weakness through which hot fluids may circulate beyond the Dakota aquifer. Thus, Seasat lineaments mapped along the structural high of the Chadron arch would indicate zones of hot water circulation at relatively shallow depths as the sediments dip up eastward toward the arch.

\section{CONCLUSION}

It has been shown that Seasat imagery does contribute to delineation of subtle structures difficult to define in any way other than through drilling. The imagery is useful as a preliminary exploration tool in areas of little physiographic relief, such as the mid-continent of the U.S., and can be used for reconnaissance of large areas. It can be used to locate surface expressions of basement structure and may aid in pinpointing specific areas for further study. In combination with other geologic and geophysical data the imagery can be a valuable exploration tool.

\section{ACKNOWLEDGMENTS}

I thank Will Gosnold, University of Nebraska, Frank Osterwald, U.S. Geological Survey, and Al Schisler, Golden, Colorado, for taking the time to talk to me about the tectonics of western Nebraska. Grant Heiken of the Los Alamos National Laboratory provided encouragement throughout the project, especially so in the beginning. Thorough reviews by Will Gosnold, Ron Blom, Jet Propulsion Laboratory, and Fraser Goff, Los Alamos National Laboratory, are greatly appreciated. 
APPENDIX

\section{COMPARISON WITH KNOWN STRUCTURE}

Some very interesting relations may be observed by comparing Plates 2 and 4. Anticlines $a$ and $c$ and syncline $b$ on Plate 2 seem to correlate with lineaments $a, b$, and $c$ on $P$ late 4 . The Tineaments may reflect the strike of bedding or may represent jointing parallel to the axes of the folds. Billings (1972) states that this kind of jointing is often observed. F. W. Osterwald (U.S. Geological Survey, Golden, Colorado, personal communication 1980) also believes that joints are seen easily on satellite imagery. In contrast, syn$c l i n e s d$ and $f$ and anticline $e$ do not lie on a line with lineaments $d, e$, and $f$. These lineaments do not reflect strike of the beds and are less Tikely joints; faulting or fracturing is possible here. Furthermore, lineament $\underline{\mathrm{g}}$ corresponds well with fault $\mathrm{g}$; the fault zone is visible on the Seasat image. To the south of lineament $\frac{g}{g}$ lie several lineaments on the same trend. If these lineaments reflect fauTts, they may indicate a fault system $30 \mathrm{~km}$ wide. The number of lineaments and the extent of faulting indicated on Plates 2 and 4 demonstrate that this fault zone is a major basement structure. Likewise, an excellent correlation exists between lineament $h_{1}$ and fault $h$. Again, this structure is probably a Precambrian feature; this is a long fauTt that extends southeast to an area of steep dip and further beyond to another basement fault along the same trend off the study area (Cole 1962). Lineament $\underline{h}_{2}$ that splays off from lineament $h_{1}$ and lineaments $h_{3}$ and $h_{1}$ are also part of the lineament system and most likely part of the fautt system. These four linears reinforce the theory that fault $\underline{h}$ is a major basement feature. To the north, lineaments also reflect a significant trend; the eastern part of the Platte River on the study area is structurally controlled for $30 \mathrm{~km}$ as it parallels the strike of the Cambridge arch. To the east off the map, the crest of the arch swings south as the river flows east. Several lineaments, $i_{1}$ and $i j$ this trend. The lineaments may represent the furthes $\bar{t}$ extent $\bar{t}^{2}$ of the changing course of the river, but the striking linearity of these features suggests that the river course is structurally controlled. Moreover, these lineaments may reflect some shearing, as lineament $i_{3}$ offsets $i_{1}$ and $\dot{i}_{2}$. Perhaps there has been right-lateral strike-slip movement in this area. Shèring also is indicated where lineament $\mathrm{g}$ and lineaments to the southwest form a characteristic ' $\mathrm{Nu}^{\prime}$ pattern (Peterson 1979), indicating left-lateral shearing. Other ' $\mathrm{Nu}$ ' patterns are seen to the north of these lineaments.

Further evidence for structural control of drainage is shown in the Middle Loup River system. Lineaments $\underline{j}_{1}, \underline{j}_{2}$, and associated 1 ineaments result from an east-west al ignment of sand duries near the edges of the river. Yet, such alignments do not correspond solely to wind action, as Russell (1929) supposed. Two lines of evidence suggest basement control of these lineaments. The first is a parallelism of the lineaments to steep aeromagnetic gradient $\underline{j}$, although at a slight angle to aeromagnetic gradient $i$, suggesting faulting. Indeed, there is a striking alignment of gradient $\underline{j}$ and lineaments $\underline{j}_{1}$ and $\underline{j}_{2}$. Second, the western edge of Plate 2 shows that the Middle Loup River follows the crest of the Cambridge arch. It is strongly suspected that the river and dunal patterns are controlled by basement structure and that these lineaments reflect more than surficial processes. Very possibly basement faulting is showing through the aeolian deposits. 
This east-west trend parallels the west-plunging folds to the southwest that probably are controlled by salt tectonics. Yet, the evidence indicates that structural control by the arch is dominant near the Middle Loup River. Notably, the west-plunging folds $\underline{k}_{1}, \underline{k}_{2}$, and $\underline{k}_{3}$ south of the South Platte River strike obliquely to lineaments $k_{1}, k_{2}$, and $k_{3}-3$ This suggests these $l$ ineaments are not related solely to salt tectonics. In fact, the influence of the arch seems to be dominant over simple salt movement. Perhaps the two processes combine to create tectonic features; for example, lineament $\underline{k}_{4}$ has a stronger east-west trend that parallels syncline $\underline{k}_{4}$.

Yet, in the area of the arch, control of structure and tectonics by the arch dominates, with periodic uplift causing deformation. Coupled with salt tectonics resulting from the deposition of Permian evaporites, the amount of deformation increases dramatically.

\section{REFERENCES}

Adams, J., "Active Tilting of the United States Midcontinent: Geodetic and Geomorphic Evidence," Geology, $\underline{8}, 442-446$ (1980).

Barr, C. R. and A. M. Bieber, "Permian Reefing on the Chadron Arch," 0il and Gas Journal, 59, no. 36, 212-219 (1961).

Bayley, R. W. and W. R. Muehlberger, "Basement Rock Map of the United States, Exclusive of Alaska and Hawaii," U.S. Geological Survey Map, 2 sheets, scale $1: 2500000$ (1968).

Billings, M. P., Structural Geology: Englewood Cliffs, New Jersey, PrenticeHall Inc., 606 p. (1972).

Burchett, R. R., "Geologic Bedrock Map of Nebraska," Nebraska Conservation and Survey Division Map, scale 1:1000 000 (1969).

Burchett, R. R. and M. P. Carlson, "Structural Contour Map -- Top of Lansing," Nebraska Conservation and Survey Division Map, scale 1:250 000 (1963a).

"Structural Contour Map -- Top of Stone Corral," Nebraska Conservation and Survey Division Map, scale 1:250 000 (1963b).

"Structural Contour Map - - Base of Kansas City," Nebraska Conservation and Survey Division Map, scale 1:250 000 (1963c).

Cannon, M. S., C. A. Tabet, and Y. Eckstein, "A Low Enthalpy Convective System in Western Ohio," Geothermal Resources Council Transactions, 4, 105-108 (1980).

Carlson, M. P., "Configuration of Precambrian Surface in Nebraska," Nebraska Conservation and Survey Division Map, scale 1:500 000 (1966).

Cole, V. B., "Configuration of Top of Precambrian Basement Rocks in Kansas," State Geological Survey of Kansas, $0 i 1$ and Gas Investigations 26, Map, scale $1: 633600(1962)$.

Curtis, G. R., "Warner Field," in Kansas 0il and Gas Fields, II, Western Kansas: Wichita, Kansas GeologicaT Society, 192-197 (1959). 
DeGraw, H. M., "Geology of the Pre-Tertiary (Principally Pre-Chadron) Surface in Western Nebraska," Nebraska Conservation and Survey Division Map, scale $1: 500000$ (1968).

Elachi, C., "Spaceborne Imaging Radar: Geologic and Oceanographic Applications," Science, 209, 1073-1082 (1980).

Farquhar, 0. C., "The Precambrian Rocks of Kansas," State Geological Survey of Kansas Bulletin, 127, Part 3, 122 p. (1957).

Goldich, S. S., E. G. Lidiak, C. E. Hedge, and F. G. Walthall, "Geochronology of the Midcontinent Region, United States, Part 2, Northern Area, "Journal of Geophysical Research, 71, 5389-5408 (1966).

Gosnold, W. D., "Usefulness of Heat Flow Data in Regional Assessment of Low Temperature Geothermal Resources with Special Reference to Nebraska," Geothermal Resources Council Transactions, $\underline{5}, 79-82$ (1981a).

"Geothermal Investigations in Nebraska: Methods and Results," in C. A. Ruscetta and D. Foley, eds., Geothermal Direct Heat Program, Glenwood Springs Technical Conference Proceedings, 1, 187-204 (1981b).

King, P. B., The Tectonics of Middle North America: Princeton, Princeton University Press, $203 \mathrm{p} .(1951)$.

Larson, W. S., "Ackman Field and Environs, Southwestern Nebraska," American Association of Petroleum Geologists Bulletin, 46, 2079-2089 (1962).

Lee, W. and D. F. Merriam, "Preliminary Study of the Structure of Western Kansas," State Geological Survey of Kansas, $0 i 1$ and Gas Investigations 11, 23 p. $(1954)$.

Lidiak, E. G., "Buried Precambrian Rocks of Nebraska," Geological Society of America Abstracts with Programs for 1969, Part 2, 17 (1969).

"Precambrian Rocks in the Subsurface of Nebraska," Nebraska Geological Survey Bulletin 26, 41 p. (1972).

Lillesand, T. M. and R. W. Kiefer, Remote Sensing and Image Interpretation: New York, John Wiley and Sons, Inc., $61 \overline{2 \mathrm{p} .(1979) .}$

Merriam, D. F. and W. R. Atkinson, "Tectonic History of the Cambridge Arch in Kansas," State Geological Survey of Kansas, $0 i 1$ and Gas Investigations 13, 28 p. $(1955)$.

Midcontinent Hot Dry Rock Study Group, "Quarterly Progress Report; September, October, and November, 1980 on Subcontract 4-X60-2133K-1, "Los Alamos Scientific Laboratory unpublished report, B1-B7 (1980).

Moore, V. A. and R. B. Nelson, "Effect of Cambridge-Chadron Structural Trend on Paleozoic and Mesozoic Thickness, Western Nebraska," American Association of Petroleum Geologists Bulletin, 58, 260-268 (1974). 
Osterwald, F. W. and B. G. Dean, "Preliminary Tectonic Map of Western Nebraska and Northwestern Kansas Showing the Distribution of Uranium Deposits," U.S. Geological Survey Map MF 129, scale 1:500 000 (1958).

"Relation of Uranium Deposits to Tectonic Pattern of the Central CorditTeran Foreland," U.S. Geological Survey Bulletin, 1087-I, 337-390, plates (1961).

Peterson, R. M., " $0 i 1$ and Gas Exploration by Pattern Recognition of Lineament Assemblages Associated with Bends in Wrench Faults, in F. Shahrokhi and T. Paludan, eds., Remote Sensing of Earth Resources, 8, 29-59 (1979).

Rascoe, B. and D. L. Baars, "Permian System," in Geologic Atlas of the Rocky Mountain Region, U.S.A: Denver, Rocky Mountain Association of Geologists, 143-165 (1972).

Russel1, W. L., "Drainage Alignment in the Western Great Plains," Journal of Geology, 37, 249-255 (1929).

Stanley, K. 0., "Tectonic Implications of Tertiary Sediment Dispersal on the Great Plains East of the Laramie Range," in Twenty-third Annual Field Conference - 1971, Wyoming Geological Association Guidebook, 65-70 (1971).

Stanley, K. 0. and W. J. Wayne, "Epeirogenic and Climatic Controls of Early Pleistocene Fluvial Sediment Dispersal in Nebraska," Geological Society of America Bulletin, 83, 3675-3690 (1972).

Swanberg, C. A. and P. Morgan, "The Linear Relation Between Temperature Based on the Silica Content of Ground Water and Regional Heat Flow: A New Heat Flow Map of the United States," Pure and Applied Geophysics, 117, 227-241 (1978).

Woollard, G. P., "Areas of Tectonic Activity in the United States as Indicated by Earthquake Epicenters," American Geophysical Union Transactions, 39, $1135-1150$ (1958).

Wulf, G. R., "Chadron Arch Could Offer Big Potential to 0il Hunters," 0il and Gas Journal, 62, no. 8, 148-151 (1964).

Zietz, I., E. R. King, W. Geddes, and E. G. Lidiak, "Crustal Study of a Continental Strip from the Atlantic Ocean to the Rocky Mountains," Geological Society of America Bulletin, 77, 1427-1447 (1966). 


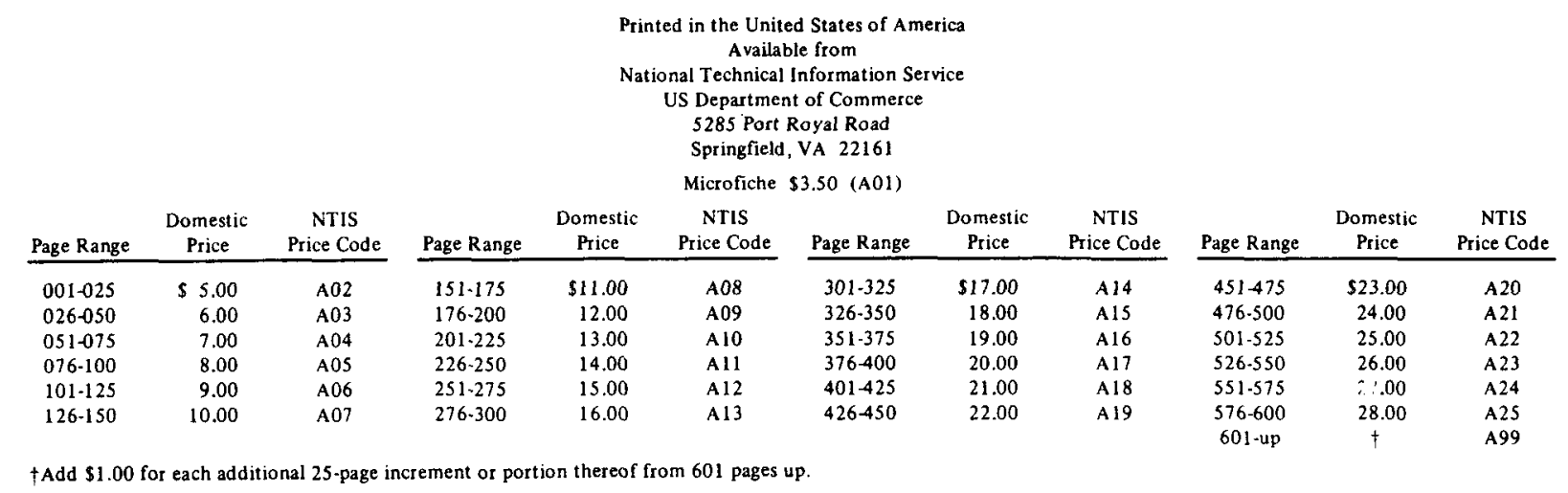


PLATE 1 PRECAMBRIAN LITHOLOGY, GEOTHERMALAND

RADIOMETRIC AGE CORRELATIONS, NEBRASKA

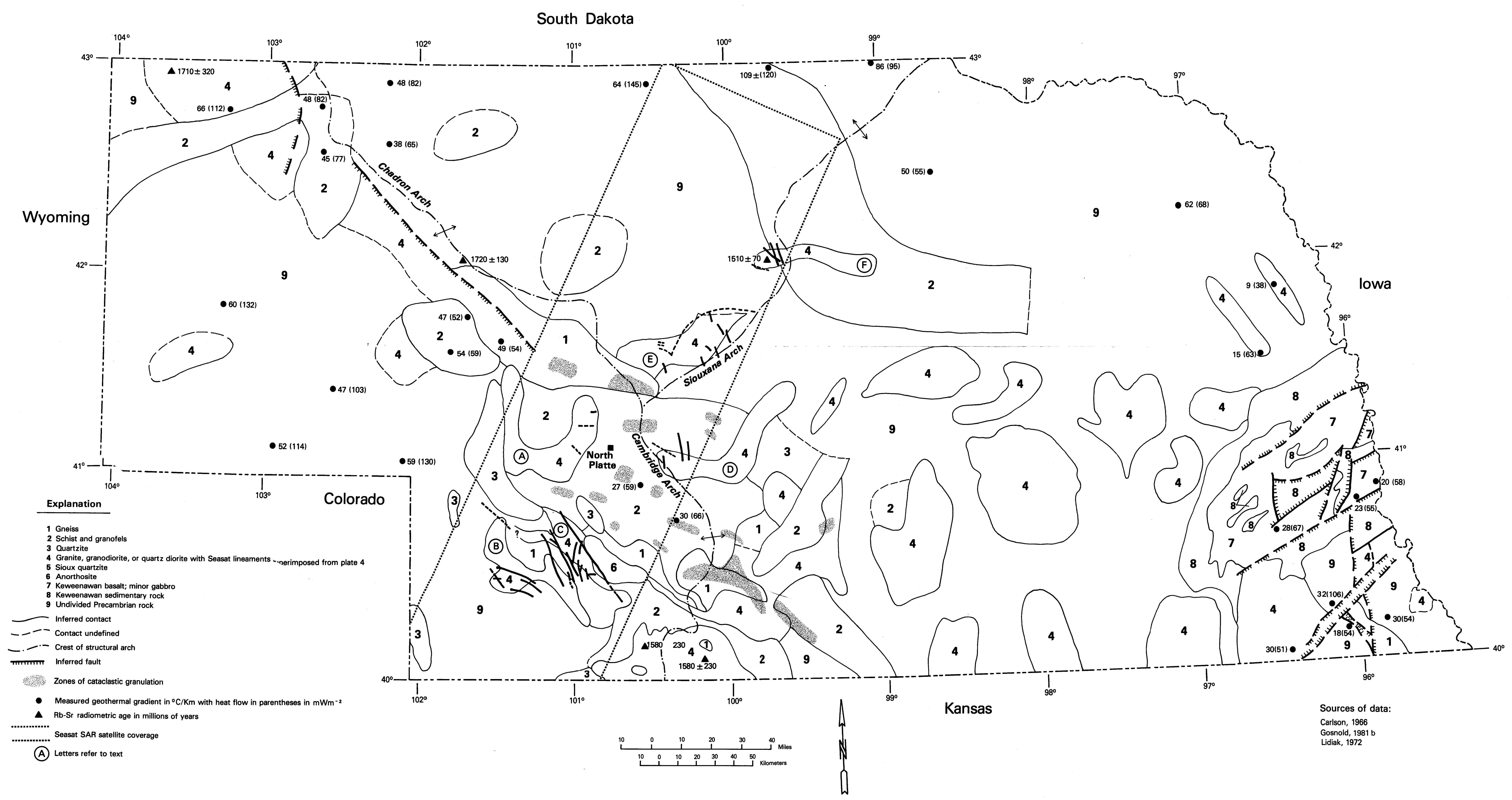


PLATE 2 KNOWN TECTONIC FEATURES, WESTERN NEBRASKA

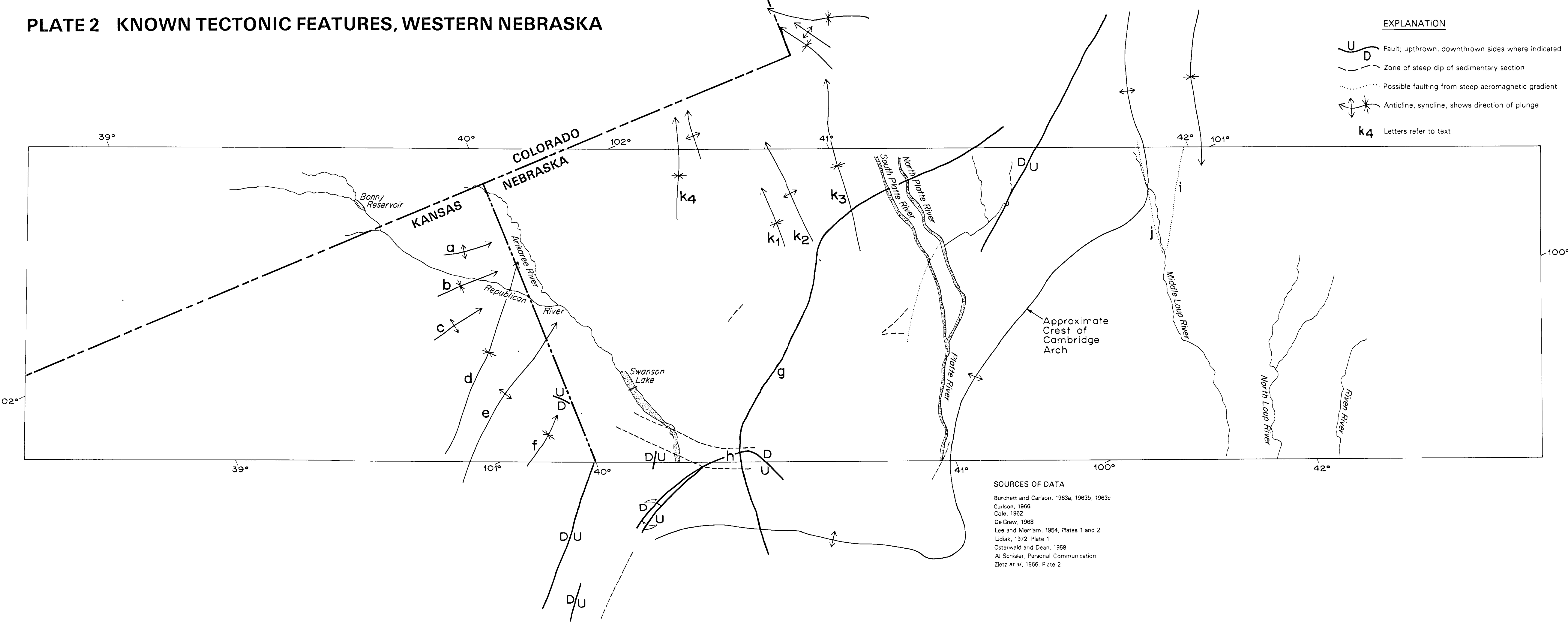

PLATE 3

SEASAT SAR SATELLITE IMAGE, WESTERN NEBRASKA
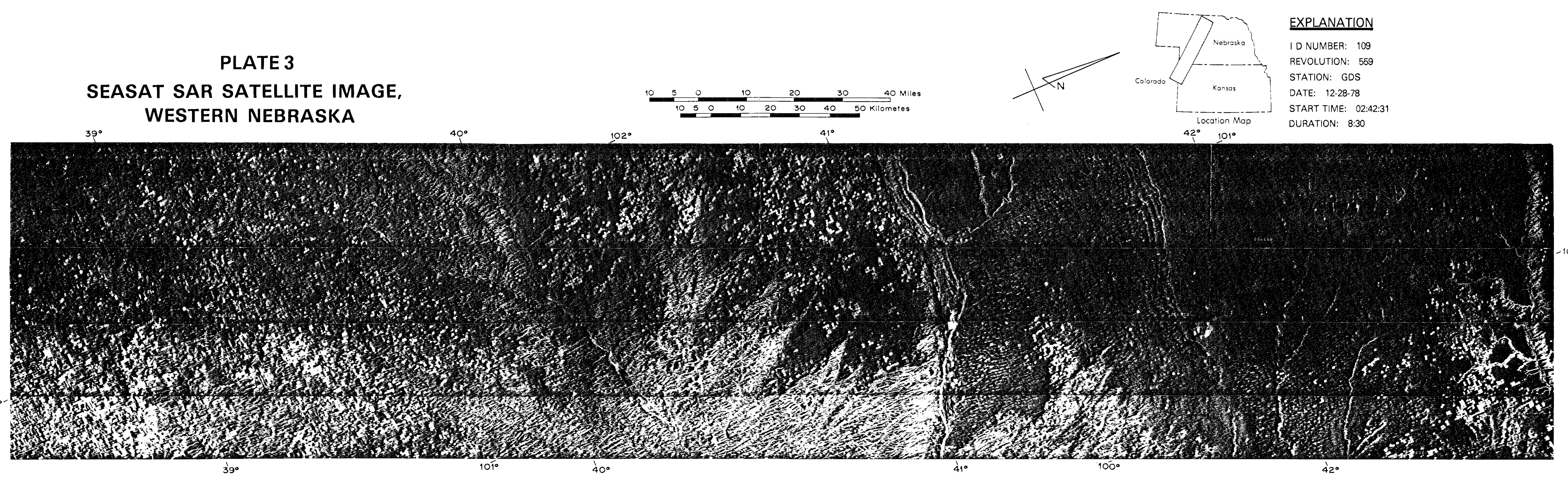

PLATE 4 STRUCTURAL INTERPRETATION BASED ON SEASAT SATELLITE IMAGERY, WESTERN NEBRASKA

EXPlanation

Strong Lineament

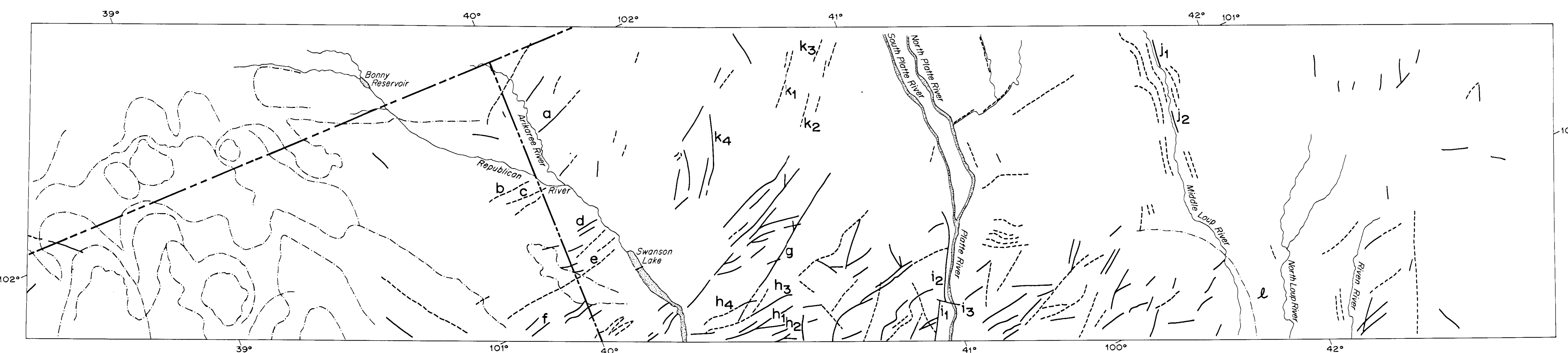

